\title{
PATRIOTYCZNA POSTAWA KARDYNAŁA STEFANA WYSZYŃSKIEGO W ŚWIETLE ZAPISKÓW WIĘZIENNYCH
}

\author{
„Dusza radowała się pełnią kielicha, \\ który Kościół podaje słudze swemu, \\ by umiał dziękować za łaski Boże dla Narodu"1
}

Stefan kard. Wyszyński

Współczesne czasy stawiają patriotycznej postawie Polaka poważne wyzwania. Nie są one bowiem łatwe czy to $z$ powodu nadmiaru okoliczności, wobec których patriotyczne opowiedzenie się jest nieodzowne, czy też z braku intensywnego kultywowania takiej postawy w wychowaniu i w codziennym życiu, w końcu zaś z powodu niewystarczającej liczby mistrzów stanowiących wzorzec patriotycznego postępowania $\mathrm{z}$ charyzmatem uczenia takiej postawy. Można nawet postawić sobie trudne pytanie, czy wobec pośpiechu życia, politycznej i gospodarczej aktywności oraz utylitarnych i hedonistycznych podstaw ludzkich obserwowanych we współczesnym świecie, na patriotyzm, czy choćby na refleksję o nim, jest jeszcze miejsce. Takie postawienie problemu ma prawo być odczytane jako prowokacyjne, albowiem wiadomo, że patriotyzmu, miłości ojczyzny i działania dla jej dobra nie mierzy się korzyścią lub przyjemnością, ale są one skutkiem wewnętrznego imperatywu płynącego z dobrze ukształtowanego sumienia. Jednak obserwacja codziennej rzeczywistości skłania do refleksji na temat relacji: obywatel - ojczyzna.

Prymas Tysiąclecia, kard. Stefan Wyszyński, z całą pewnością może być nauczycielem i mistrzem postawy patriotycznej. Świadczą o tym nie tylko jego wypowiedzi z okresu służby Kościołowi i ojczyźnie, ale również, w najwyższym stopniu spójna i konsekwentna

${ }^{1}$ S. W y s z y ń s k i, Zapiski więzienne, Warszawa-Ząbki, 2001, s. 31. 
wobec głoszonych idei, postawa. $Z$ racji bogatej faktografii $w$ niniejszym artykule zostanie przedstawiony tylko jej wycinek, ale z bardzo dramatycznego okresu życia prymasa, to jest $\mathrm{z}$ okresu jego uwięzienia. Oderwany od rzeczywistości kościelnych i państwowych, wydawałoby się skazany na duchowy uwiąd, pokazał wówczas, że rozwój duchowy, w tym też życie postawą miłości ojczyzny, może i powinno rozwijać się niezależnie, pomimo fizycznych i duchowych przeszkód.

W celu ukazania patriotycznej postawy prymasa zostanie zatem najpierw krótko omówiony patriotyzm jako cnota i postawa społeczna, a następnie, na tym tle, odwołując się do więziennych notatek i niektórych pism oraz wypowiedzi z lat między konsekracją biskupią a uwolnieniem z Komańczy, ukazać pełnię i blask patriotyzmu Prymasa Tysiąclecia.

\section{Czym jest patriotyzm?}

Odpowiedź na to pytanie implikuje najpierw pytanie o podmiot. Patriota to człowiek w swej relacyjnej kondycji - i w jej konsekwencji - powołany do życia we wspólnocie. „Bez akceptacji tego społecznego charakteru życia ludzkiego i to nie tylko w sensie teoretycznym, ale także jako świadomego sposobu na życie, nie jest możliwe wzbudzenie w człowieku prawdziwego ducha patriotyzmu". ${ }^{2}$ Ten charakter relacyjny wymaga więc odpowiedniego ukierunkowania rozumu i woli oraz towarzyszących temu uczuć na konkretny przedmiot, którym jest ojczyzna jako wspólnota. Patriotyzm zatem to „bezwarunkowe umiłowanie ojczyzny $\mathrm{z}$ gotowością poświęcenia dla niej swych sił, zdolności, nawet życia". ${ }^{3}$ Przyjęcie takiego sformułowania wymaga jednak pewnego dopowiedzenia.

Pierwsze $\mathrm{z}$ nich wynika $\mathrm{z}$ faktu istnienia wielkiej liczby skojarzeń związanych z ojczyzną. Z wielości jej definicji, z których każda z konieczności obejmuje tylko pewien aspekt znaczeniowy, dla naszych rozważań można przyjąć tę, która opisuje ojczyznę jako całość narodu i jego dziejów, języka, historii i kultury, bogactw materialnych i duchowych, przeszłości i perspektyw. ${ }^{4}$ Jest to społeczność natural-

2 J. Nagórny, Wychowanie do patriotyzmu w nauczaniu Jana Pawła II, w: J. Nagórny, T. Zadykowicz (red.), Formacja moralna, formacja sumienia, Lublin 2006, s. 130.

${ }^{3}$ T. S i k o r s k i, Patriotyzm, w: A. Z u be r b i e r (red.), Stownik teologiczny, Katowice 1989, 2, s. 66 .

4 Wieloaspektowość terminu "ojczyzna" trafnie ujął M. Krąpiec, pisząc: "Ojczyznę stanowią i moi rodzice, i rodziny, i dom rodzinny, i bliscy, i ziemia macierzysta, i wioska czy mia- 
na, a z racji obejmowania wszystkich zasadniczych składników koniecznych do egzystencji - bardzo ważna, najważniejsza po rodzinie. Dlatego powinna być przedmiotem miłości, życzliwości i czci. Te relacje, analogiczne do panujących w kochającej się rodzinie, znajdują zresztą odbicie nawet w jej etymologii: „ojczyzna” to łacińskie patria, w którym pobrzmiewa pater - „ojciec”. Tutaj też jest miejsce na drugie, znacznie ważniejsze, dopowiedzenie.

Z teologicznego punktu widzenia na ojczyznę należy patrzeć w kategoriach Bożego daru, dającemu narodowi i poszczególnym jego członkom możliwość egzystencji i rozwoju. Już z tego powodu wymagana jest - jako odpowiedź człowieka - postawa pełna miłości do niej, oddania i szacunku. Podstawę stanowi więc wdzięczność dla niej jako dla kraju i narodu za konkretny, ukonstytuowany w warunkach gospodarczych i kulturowych byt. ${ }^{5}$ II Sobór Watykański dokładnie wskazuje ten teologalny aspekt egzystencji człowieka w przestrzeni kulturowej własnej ojczyzny i narodu, zalecając mu życie „dla Boga i Chrystusa w uczciwej atmosferze (...), pielęgnując prawdziwą i czynną miłość ojczyzny". ${ }^{6}$ Również omawiając współpracę i powinności w ramach życia publicznego, wskazuje na dobro wspólne jako podstawę świadczeń na rzecz państwa usług materialnych i osobistych, pouczając, że nie uda się właściwie zrealizować założeń tego dobra, o ile obywatele nie będą pielęgnować wielkodusznej i wiernej miłości ojczyzny, w taki sposób, aby mieć na uwadze dobro całej rodżiny ludzkiej. ${ }^{7}$ Jeżeli zaś przyjmie się, że miłość to stałe nastawienie życzliwości przy pragnieniu dobra $\mathrm{i} \mathrm{z}$ chęcią czynienia go, ${ }^{8}$ to pragnienie dobra dla ojczyzny jest równoznaczne z postawą czynnej milości, która jest istotą patriotyzmu. ${ }^{9}$

sto, i szkoła, i szpital, i teatr, i wspólna kultura w moim rodzinnym języku wyrażona, i historia, i projektowanie przyszłości mojej oraz moich najbliższych”; por. W. S e r e m a k, Patriotyzm nowego czlowieka, w: A. J. N o w a k, T. P a s z k o w s ka (red.), Homo novus, Lublin 2002, s. 330 .

5 Por. S. O 1 e j n i k, Moralność życia spolecznego, Warszawa 1993, s. 263-267.

6 Dekret o misyjnej działalności Kościoła Ad gentes divinitus nr 15, w: Sobór Watykanski II. Konstytucje. Dekrety. Deklaracje, Poznań 2002.

7 Por. Konstytucja duszpasterska o Kościele w świecie współczesnym Gaudium et spes nr 75, w: tamże.

8 Por. T. Ś 1 i p k o, Zarys etyki ogólnej, Kraków 1984, s. 378-379.

9 Jak pisze T. Ślipko: „Związek cnoty miłości z dobrem sprawia, że przekształca się ona w naczelną siłę motoryczną rozwoju innych cnót. Lgnąc do dobra i dążąc do jego urzeczywistnienia stwarza potężny bodziec do rozwijania wszystkich sprawności moralnych, umożliwiających na różne sposoby spełnienie tego zadania"; por. tamże. 
Patriotyzm, wypływający z pragnienia prawdziwego dobra i pomyślności dla ojczyzny, nakłada na człowieka zasadnicze obowiązki. Z szacunku zatem i czci wobec ojczyzny, jako daru Bożego, wypływa obowiązek najważniejszy, czyli solidarność obywateli z narodem, który ich jednoczy i którego są członkami. W imię tego obowiązku obywatel będzie musiał dać wielki wysiłek na rzecz interesu narodowego, nieraz $\mathrm{w}$ połączeniu $\mathrm{z}$ poważną ofiarą, wyrzeczeniem lub poświęceniem osobistych dóbr. ${ }^{10}$ Przykład uwięzionego prymasa w kontekście jego ofiary $z$ godziwych dóbr w imię dobra narodu jest jasny $i$ przekonywający.

Miłość ojczyzny, której zewnętrznym przejawem jest patriotyzm, nakłada jeszcze inne obowiązki, które - o ile nawet nie są wielkie i heroiczne - wymagają jednak wytrwałości i wielkoduszności, a zwłaszcza stałości w ich wykonywaniu. ${ }^{11}$ Miłość wymaga więc uznania swej ojczyzny i przyznawania się do niej, niezależnie jakie okoliczności dane są do przeżywania. Postawa taka jest bezpośrednią konsekwencją przeżywania relacji $\mathrm{z}$ nią $\mathrm{w}$ kategoriach Bożej woli. Miłość ojczyzny wymaga ponadto spojrzenia w prawdzie. Poprawna relacja wyklucza postawę mesjanistyczną, błędną apoteozę lub tolerancję na obecne w niej zło. Miłość ojczyzny będzie wymagała natomiast postawy pokory, to znaczy stawania wobec niej w prawdzie i oceniania związanych z nią wydarzeń według obiektywnych Bożych praw. Oznacza to także, że zło obecne w jej strukturach należy cierpliwie usuwać bez zrywania jednak żywotnych z nią relacji. $\mathrm{Z}$ postawą prawdy wiąże się $\mathrm{w}$ końcu chęć poszerzania o niej wiedzy i jako element szczególny-umiłowania jej dorobku kulturowego i dóbr narodowych przez otaczanie ich szacunkiem i czcią.

Elementem fundamentalnym jest służba na rzecz ojczyzny, przy czym służba wojskowa jest tylko jednym z elementów. Idea takiej postawy jest oparta na wielkodusznym podporządkowywaniu własnych interesów celom zasadniczym całego narodu przez poświęcanie sił, troski i starań dobru wspólnemu. Objawia się to głębokim zainteresowaniem sprawami ojczyzny i solidną pracą dla jej dobra.

Takie ujęcie patriotyzmu, nie wyczerpujące $\mathrm{z}$ całą pewnością całości zagadnienia, pozwala jednak przynajmniej w zarysach ująć jego istotę i odnaleźć w postawie prymasa podczas uwięzienia cechy cha-

\footnotetext{
${ }^{10}$ Por. tenże, Zarys etyki szczegółowej, Kraków 1928, 2, s. 257.

${ }^{11}$ Por. S. O 1 e j n i k, Moralność życia społecznego, s. 271-273.
} 
rakterystyczne patriotyzmu, przede wszystkim stałą pamięć i troskę o sprawy ojczyzny, narodu i Kościoła. Objawiało się to z jednej strony $\mathrm{w}$ gorliwej modlitwie $\mathrm{w}$ tych intencjach, ale $\mathrm{z}$ drugiej - $\mathrm{w}$ przygotowywaniu planów dla konkretnej przyszłej pracy na rzecz tych środowisk. Poza tym kardynał niejednokrotnie objawiał wielką miłość i życzliwość do otaczającej go rzeczywistości: ludzi, przyrody i różnych okoliczności, w czym widział realizującą się wolę Bożą. Nie oznaczało to oczywiście zgody na zło, którego był niejednokrotnie naocznym świadkiem. Przejawem jego wręcz heroicznie przeżywanej miłości do Polski był zdecydowany sprzeciw wobec zła, które dotykało nie tyle jego samego, ile całą ojczyznę.

\section{Postawa patriotyczna Prymasa Tysiąclecia w czasie jego uwięzienia}

Kardynał Stefan Wyszyński, prymas Polski, został aresztowany 25 września 1953 r., natomiast powrócił do Warszawy 28 października 1956 r. $^{12}$ Podczas internowania $\mathrm{w}$ postawie prymasa można zauważyć w świetle Zapisków więziennych ewolucję jego duchowej postawy od niepozbawionej emocjonalności i mocno angażującej się w okoliczności uwięzienia do głębokiego wyciszenia i oddania calości spraw w ręce Bożej Opatrzności. Można pokusić się o stwierdzenie, że prymas przeszedł $\mathrm{w}$ więzieniu duchowy przełom. Niewątpliwie taka ewolucja postawy duchowej w jakiś sposób odcisnęła się na jego myśleniu i postępowania $\mathrm{w}$ przestrzeni spraw polityczno-społecznych, w tym również dotyczących patriotyzmu i szeroko pojętej miłości ojczyzny oraz zaangażowania w jej sprawy, jednak należy stwierdzić, że w różnych aspektach tej postawy zmiany są stosunkowo niewielkie. Prymas trafił $\mathrm{w}$ miejsce internowania jako człowiek głęboko uformowany i mocno zakotwiczony w umiłowaniu własnego kraju. Wydarzenia więzienne jedynie pomogły te elementy wyeksponować i ukazać.

W postawie i wypowiedziach prymasa bez trudu można zauważyć wszystkie aspekty konstytuujące patriotyczną postawę. Niektóre z nich są wyrażane bezpośrednio, inne można wyprowadzić z jego

\footnotetext{
12 Przebieg uwięzienia prymasa Polski był następujący: 26 IX - 12 X 1953: Rywałd Królewski k. Reszla; 12 X 1953 - 6 X 1954: Stoczek Warmiński; 6 X 1954 - 27 X 1955: Prudnik Śląski; 27 X 1955 - 28 X 1956: Komańcza. Wraz z prymasem uwięzieni byli ks. S. Skorodecki i s. L. Graczyk.
} 
słów kierowanych do osób, z którymi musiał się kontaktować. Wykazanie wszystkich ,patriotycznych” momentów z okresu jego uwięzienia byłoby zatem dość trudne, chyba jednak też niekonieczne, zważywszy na konsekwentną $\mathrm{w}$ tej dziedzinie jego postawę. Siedzenie, opierając się na Zapiskach, zachowania kardynała niezbicie bowiem powinno doprowadzić do wniosku, że on taką postawą po prostu żył. W tym paragrafie zatem ograniczymy się do kilku charakterystycznych przykładów.

Pierwszym z nich jest więc troska o dobro wspólne i odpowiedziałność za ogół ludzkich spraw, która objawiła się w sytuacji drobnej, ale bardzo symptomatycznej. Kardynał, będąc już w Rywałdzie, niepokoi się o pracowników budujących Dom Arcybiskupi w Warszawie, którym z racji jego nieobecności, a być może i bp. Baraniaka, czego nie był pewien, ${ }^{13}$ nie zostanie wypłacona pensja. Przedmiotem zdziwienia funkcjonariusza, którego informuje o tym problemie, jest stwierdzenie prymasa, że ,sprawa moich zobowiązań wobec ludzi pracujących jest dla mnie ważniejsza niż moje więzienie". ${ }^{14}$ Ta krótka wymiana zdań stanowi również jeden z bardzo wielu przykładów, w których prymas w sposób delikatny, acz stanowczy, wykazuje zauważane przez niego słabości systemu, z którym go wbrew jego woli skonfrontowano, i na którego tle w pełni uwidacznia się jego głęboko humanitarna i patriotyczna postawa.

Innym elementem, na który prymas zwracał ogromną uwagę i który był przedmiotem jego zatroskania, była racja stanu i obraz Polski w świecie. Myśl o tym nie opuszczała go nawet w sytuacjach bardzo dramatycznych, np. w momencie aresztowania, gdy stwierdził, że decyzja rządu ${ }^{15}$ o odsunięciu go od urzędów kościelnych i aresztowa-

13 Bp A. Baraniak został aresztowany w nocy 25/26 IX 1953 i osadzony w więzieniu na ul. Rakowieckiej w Warszawie, por. W. J. Wy s o cki, Osaczanie Prymasa, Warszawa 2002, s. 38. Prymas o jego uwięzieniu dowiedział się dopiero w Komańczy, por. S. W y s z y ńs k i, Zapiski więzienne, s. 198.

${ }_{14}$ Tamże, s. 31; por. Dokument Nr 6, 15.10.1953, w: Stefan Kardynat Wyszyński Prymas Polski $w$ dokumentach aparatu bezpieczeństwa PRL (1953-1956), Warszawa 2001, s. 20 (dalej: DAB). Ten niewielki fragment pokazuje również, jakby mimochodem, ogromny pietyzm prymasa wobec pracy ludzkiej i pracowników, co jest wskazaniem jego patriotycznej postawy, której jedną z zasadniczych cech jest dawanie przez obywatela wysiłku pracy na rzecz wspólnoty narodowej.

15 Por. tamże, s. 3. Chodzi o uchwałę Prezydium Rządu PRL z dn. 24 IX 1953 r. Nr 700/63, która postanawia ,zakazać ks. arcybiskupowi Stefanowi Wyszyńskiemu wykonywania funkcji wynikających z piastowania przezeń dotąd stanowisk kościelnych”. W związku z tym prymas 
niu jest „wysoce szkodliwa dla opinii o Polsce”, ${ }^{16}$ tworząc dla niej nieprzychylny klimat $\mathrm{w}$ propagandzie zagranicznej. Myśl o nadrzędności racji stanu nad jakimikolwiek innymi argumentami politycznymi nie opuszczała prymasa nawet po ciężkim, pełnym bolesnych doświadczeń, pierwszym roku uwięzienia. W jej imię był gotów rozmawiać z rządem i przedstawiać argumenty merytorycznej dyskusji dla dobra kraju mimo tworzonych przez władzę atmosfery niedomówień. Ubolewał przy tym, że obecna sytuacja, trudna dla niego samego, przedstawia rząd $\mathrm{w}$ dalszym ciągu $\mathrm{w}$ niekorzystnym świetle ${ }^{17}$. Jest godne zauważenia, że w kontekście tak rozumianej racji stanu w myśleniu kardynała zawsze pojawia się związana $\mathrm{z}$ tym sytuacja Kościoła, który jest związany z polskim społeczeństwem. Ta postawa objawiła się szczególnie mocno w ostatnim roku uwięzienia, swoiście "sprowokowana" rozmową toczącą się wokół powrotu prymasa do Warszawy. ${ }^{18}$ Kardynał Wyszyński stwierdził wówczas, że znacznie ważniejszą sprawą jest poszanowanie spraw Kościoła w Polsce, których jego osobisty przypadek jest tylko fragmentem, a którego nie można odrywać od całości spraw eklezjalnych. ${ }^{19}$ Natomiast wszystkie sugestie rozwiązań sprzeniewierzających się posłudze biskupiej i prymasowskiej, którą kardynał postrzegał jako jedyną i niezbywalną, odrzucane były już w zalążku. W ten sposób zareagował na propozycję rezygnacji z urzędu prymasa Polski, co ewentualnie mogłoby przyspieszyć zwolnienie ${ }^{20}$ a nieco infantylne sugestie s. Graczyk o stosowniejszym dla prymasa miejscu pobytu jednoznacznie i zdecydowanie odrzucił. ${ }^{21}$

ma opuścić Warszawę i zamieszkać w wyznaczonym klasztorze bez prawa opuszczania go aż do nowego zarządzenia władz; por. tamże.

16 S. W y s z y ń s k i, Zapiski więzienne, s. 13.

17 Por. tamże, s. 103-106.

18 Rozmowa odbyła się w Komańczy, a brali w niej udział, oprócz prymasa, bp Z. Choromański oraz ks. H. Goździewicz i ks. B. Dąbrowski; por. tamże, s. 233.

19 Por. tamże.

20 Por. W. J. W y s o c k i, Osaczanie Prymasa, s. 117. Wyszyński widział w swej posłudze patriotyczny obowiązek, stwierdzając, że na to stanowisko mianował go papież, a on sam ,woli siedzieć pod dozorem, jak iść na jakąkolwiek współpracę z Rządem"; por. tamże.

21 Por. S. W y s z y ń s ki, Zapiski więzienne, s. 196. Na sugestie siostry o wartości pobytu „na Riwierze, w słońcu”, Wyszyński odpowiedział: „Wolę polskie więzienie, gdy już nie ma dla mnie innego miejsca w Ojczyźnie, niż zagraniczne pałace”, dodając: „Miejsce biskupa polskiego jest albo przy Katedrze, albo w więzieniu, ale nie za granicą"; tamże. Wypowiedź ta rzuca światło na rozumienie przez niego idei patriotyzmu i służby ojczyźnie, co często jest powiązane z heroiczną ofiarą lub męczeństwem. 
Nieodzownym elementem służby jest ofiara. Dlatego posługiwanie Polsce i Kościołowi nie oszczędziło jej również prymasowi. Miał świadomość potrzeby ofiary i pragnął jej, obawiając się, że nie dostąpi tego zaszczytu, zazdroszcząc kolegom z seminarium, którzy ,przeszli przez obozy koncentracyjne i więzienia, większość oddała tam swe życie, kilku wróciło w stanie inwalidztwa". ${ }^{22}$ Pod koniec swojego odosobnienia kard. Wyszyński odczytuje w sposób zdecydowany lata więzienia jako udział w męce Jezusa i swój męczeński wkład w dzieje Kościoła polskiego, ${ }^{23}$ widząc w tym wyraźnie wolę Bożą. ${ }^{24}$ Bronił się jednak przed traktowaniem go jak męczennika in spe, mimo że tego nie wykluczał, ${ }^{25}$ mówiąc, iż jest przede wszystkim realistą i dopiero jako realista uznaje możliwość powołania go do męczeństwa. ${ }^{26}$ Ten realizm ukazał się $\mathrm{w}$ pełni $\mathrm{w}$ rozmowie $\mathrm{z}$ bp. Choromańskim, w której prymas dał wytyczne do rozmów z rządem o relacjach państwo - Kościół, jak i o swoim powrocie do Warszawy, wskazując, że ustępstwa ze strony Kościoła nie przyniosą mu żadnych korzyści, a więc trzeba odczekać. Prymas wskazuje gotowość podjęcia nawet nieznanych mu $\mathrm{w}$ tej chwili ofiar dla dobra wspólnoty, na której czele $\mathrm{w}$ dalszym ciągu $\mathrm{w}$ sposób formalny stoi. ${ }^{27}$ Podobnie w rozmowie ze swym byłym współwięźniem, ks. Stanisławem Skorodeckim, który odwiedził go w Komańczy 4 czerwca 1956 r., prymas pokazał się jako zdecydowany na wszystko w imię dobra i jedności Kościoła $\mathrm{w}$ Polsce. Zdając sobie bowiem sprawę z możliwości przedłużenia terminu uwięzienia, był na wszystko gotowy, widząc błogosławione skutki takiej sytuacji dla Kościoła. ${ }^{28}$

Prawdziwa postawa patriotyczna musi być osadzona na właściwej hierarchii wartości. Jej szczytem jest miłość Boga, w nurcie której należy rozwijać miłość ojczyzny, ta zaś jest nadrzędna wobec miło-

${ }^{22}$ Tamże, s. 15. Wspomina o tym również w liście do swojego ojca z dn. 17 X 1953; por. tamże, s. 45.

${ }^{23}$ Por. tamże, s. 221-222.

${ }^{24}$ Por. tamze, s. 151.

25 Por. tamże, s. 19: „Nieraz z kół rządowych zarzucano mi, że «chcę» być męczennikiem. Byłem daleki od tej myśli, chociaż tej możliwości nie wykluczałem".

${ }^{26} \mathrm{~W}$ tym kontekście jakże nietrafnie brzmi opinia s. Graczyk, według której prymas „marzy o tym, że historia w swych dziejach zachowa go jako męczennika za wiarę”, por. Kryptonim „Ptaszyńska”. Donosy na Prymasa, Londyn 1993, s. 175.

${ }^{27}$ Por., W. J. W y s o c k i, Osaczanie Prymasa, s. 127-128.

${ }^{28}$ Por. tamże, s. 125: „Wytrzymałem już tyle, wytrzymam nawet gdyby jeszcze gorsze rzeczy ze mną robili. To zresztą wszystko dla chwały i na pożytek kościoła, nie mogli nic lepszego w tej sytuacji zrobić dla kościoła i dla umocnienia pozycji kościoła w Polsce". 
ści do rodziców. Uwięziony prymas heroicznie rozwijał miłość Boga i miłość do Maryi, Jej szczególnie polecając wszystkie trudności, które napotykał $\mathrm{w}$ życiu kościelnym, politycznym i społecznym. ${ }^{29}$ Towarzyszyła mu Ona w trudnym momencie aresztowania, co zwróciło nawet uwagę aresztujących go funkcjonariuszy. ${ }^{30} \mathrm{~W}$ okresie internowania, Bóg za pośrednictwem Maryi był celem modlitw prymasa w intencjach narodu, za którym wstawiał się, widząc jego słabości i przywary. Te - jak mawiał - „kamienie” oddawał Królowej Polski, „Najbliższej Towarzyszce Trójcy Świętej”, prosząc ją o wstawiennictwo w udzielaniu łask najbardziej Polsce potrzebnych: wierności Jezusowi i Jego Kościołowi. Kardynał zdawał sobie sprawę, że więź z Bogiem i Maryją, tak charakterystyczna dla duchowości narodu, którego jest prymasem, jest rękojmią jego odrodzenia. $Z$ tego płynęła bardzo głęboka modlitewna prośba: „Pragniemy wyjednać sobie odrobinę odpocznienia, byśmy mogli wypełnić śluby nasze" 31 z nadzieją, że „Królewskie Serce Twoje okaże macierzyńską wyrozumiałość dla udręczonych dzieci swoich". ${ }^{32}$ Jest to modlitwa człowieka kochającego w Bogu swoją ojczyznę.

Drugim szczeblem właściwie pojętego patriotyzmu jest miłość do rodziców. Miłość synowska, okazywana przez prymasa swojemu ojcu $\mathrm{w}$ wysyłanych do niego listach, jest tematem samym w sobie, tu zaś istotny jest tylko jeden ze szczegółów. W liście do Rady Ministrów PRL ${ }^{33}$ prymas zwraca się z prośbą o wydanie zezwolenia na widzenie się z nim jego ciężko choremu ojcu. Nie chce bowiem, by jego nieobecność pogorszyła stan zdrowia ojca, ale argumentacja jest na wskroś Boża: kardynał bowiem poważnie ,liczy się w sumieniu z życzeniem swego Ojca”, a następnie „chce uczynić zadość jego prośbie, potrzebie mego serca oraz obowiązkom, jakie ma syn wobec Ojca". ${ }^{34}$

29 Dla ogromnego tematu maryjnej duchowości Prymasa Tysiąclecia por. np. T. S i u d y, Duchowość maryjna w życiu i nauczaniu Prymasa Tysiąclecia, w: E. W e r o n, Duchowość Prymasa Tysiąclecia, Kraków 2002, s. 77-90 (bibliog.). Dla aspektów maryjnych w Zapiskach więziennych por. np., E. W e r o n, Duchowość Prymasa Stefana Wyszyńskiego w świetle „Zapisków więziennych", Communio 123(2001) 3, s. 27-40.

${ }^{30}$ Por. S. W y s z y ński, Zapiski więzienne, s. 14; DAB dokument nr 5, s. 14, dokument nr 6, s. 17

${ }^{31} \mathrm{~S}$. W y s z y ń s k i, Zapiski więzienne, s. 72, 161. Jest charakterystyczne, że kardynał umiejscawia te teksty pod datą 3 maja.

${ }^{32}$ Tamże.

${ }^{33}$ Por. List Do Rady Ministrów PRL w Warszawie, 18 II 1955, w: S. W y s z y ń s k i, Dzieła zebrane, 1.1 (1949-1953), Warszawa 1991, s. 244; por. t e n ż e , Zapiski więzienne, s. 141.

${ }^{34}$ Tamże. 
Kolejną cechą postawy patriotycznej jest praca na rzecz i dla dobra własnego narodu. Temat ten był kard. Wyszyńskiemu szczególnie bliski. ${ }^{35} \mathrm{~W}$ okresie internowania prymas, przyglądając się ,z bliska” przedstawicielom „klasy panującej”, jak często żartobliwie nazywał członków pilnującej go ekipy, wielokrotnie dawał w Zapiskach upust swojemu zdumieniu nad ich niegospodarnością, nieporządkiem, brakiem planowego działania lub lenistwem, czego był świadkiem. ${ }^{36}$ Ważniejszym jednak aspektem jego refleksji nad pracą była świadomość jej pozytywnej wartości dla społeczeństwa, zwłaszcza takiego, które utraciło wiele ze swojego potencjału w wyniku wojny. Myśląc przede wszystkim o Polsce, prymas postrzegał więc pracę specyficznie - w kontekście wielkodusznej ofiary dla kraju, we wspólnym wysiłku, a nawet męczeństwie - jednak, jak podkreślał, „męczeństwa pracy a nie krwi". ${ }^{37}$ Dlatego od samego początku internowania prymas prowadził bardzo uporządkowany i pracowity tryb życia - wystarczy w tym celu przeczytać zamieszczone w Zapiskach plany dnia. W momencie zaś pojawienia się współwięźniów, przedstawił im krótkie i bardzo treściwe wytyczne dotyczące codziennego życia: „Będziemy się modlili, pracowali i czekali zmiłowania Pańskiego". ${ }^{38}$ Starał się więc o dostarczanie lektur, zachęcając współtowarzyszy do pisania i studiów. ${ }^{39} \mathrm{~W}$ związku z tym dużo światła na intelektualny i duchowy element pracy rzucają przygotowywane wykazy potrzebnych książek, ${ }^{40} \mathrm{o}$ które kardynał regularnie prosił, a których przysyłanie związane było $\mathrm{z}$ różnymi perturbacjami. Prymas konsekwentnie również wykazywał zainteresowanie i troskę o postępy w pracy intelektualnej ks. Stanisława i s. Leonii, chwaląc systematyczność i ganiąc brak postępów. Warto również wspomnieć, że wolnych chwilach, często na spacerze, prymas nie stronił od pracy fizycznej w ogrodzie, przycinając gałęzie, odśnieżając lub oczyszczając spacerową ścieżkę. ${ }^{41}$

${ }^{35}$ Por. np. J. M a c h n i a k, Duchowość pracy ludzkiej w myśli teologicznej kard. Stefana Wyszyńskiego, w: Duchowość Prymasa Tysiaclecia, s. 135158-; J. Ł a c h, Ksiądz Prymas Wyszyński i rolnicy, Communio 123(2001) 3, s. 378-85.

${ }^{36}$ Por. np. S. W y s z y ń s k i, Zapiski więzienne, s. 37-38, 67, 100, 108.

${ }^{37}$ Tamże, s. 19.

${ }^{38}$ Tamże, s. 39.

${ }^{39}$ Por. K. R u 1 k a, Lektury więzienne Prymasa Wyszyńskiego, AK 142(2004)1, s. 66-80.

${ }^{40} \mathrm{~S}$. W y s z y ń s k i, Dzieła, s. 236-239. Jak cenne były one dla wizji pracy pryma, niech świadczy fakt, że pierwsze zapotrzebowanie wysłał już z Rywałdu 4 października, a więc w niewiele ponad tydzień po aresztowaniu.

${ }^{41}$ Por. np. t e n ż e, Zapiski więzienne, s. 62, 93. 
Patriotyzm wypływa z określonego rodzaju sprawiedliwości zwanego sprawiedliwością współdzielczą, czyli społeczną. ${ }^{42}$ Jednakowoż nie oznacza to, że inne jej rodzaje nie stanowią elementów konstytuujących go. Dotyczy to przede wszystkim uprawnień w relacjach między dwiema osobami oraz uprawnień społeczności wobec jednostki, będącej tej społeczności członkiem. Kardynał Wyszyński wielokrotnie stwierdzał różnorakie pogwałcenia obydwu rodzajów sprawiedliwości wobec swojej osoby, więc protestował wobec nich, najczęściej jednak bezskutecznie. ${ }^{43}$ Zapiski obfitują więc w opisy wielu nadużyć ze strony władz w przestrzeni nawet elementarnej sprawiedliwości wobec więźnia, który nie może się bronić. $\mathrm{Na}$ te nadużycia prymas wskazuje bardzo konkretnie: nieprzedstawienie aktu oskarżenia i dekrętu władz sankcjonujących sytuację odosobnienia, szykany związane $\mathrm{z}$ korespondencją, również rodzinną, dostarczaniem książek i czasopism, aż do ograniczeń logistycznych (np. w pewnym momencie w Rywałdzie otrzymał zakaz wyglądania przez okno ${ }^{44}$ lub niepodanie „przez zapomnienie” nazwy miejsca uwięzienia ${ }^{45}$ ). Drastyczne pod tym względem były okoliczności lekarskiego konsylium zebranego u prymasa w Stoczku. Ponieważ w skład komisji lekarskiej weszli inni lekarze niż ustaleni poprzednio, Wyszyński poddał się badaniu tylko ze względu na trud przyjazdu podjęty przez starszego członka komisji, co świadczy o delikatności i dobroci kardynała. Jednak $\mathrm{w}$ rozmowie z komendantem Stoczka, przeprowadzonej półtora miesiąca później, prymas przedstawił swój punkt widzenia na całą sytuację. Stwierdził przede wszystkim, że relacje międzyludzkie mogą realizować się jedynie $\mathrm{w}$ atmosferze sprawiedliwości i poszanowania, a nie złośliwości, którym jako więzień jest poddawany i na przerwanie których nie ma wpływu. W obliczu takiego działania władz prymas mimo wszystko - dla dobra Kościoła i narodu - nie rezygnuje z rozmów, obiecując na zakończenie rozmowy, że „nad listem do Rządu będę myślał". ${ }^{46}$

Siedząc postępowanie władz w stosunku do uwięzionego prymasa, nasuwa się pytanie o jego reakcje w obliczu jawnej niesprawie-

42 Por. STh II-II, 61,1: „Zadaniem sprawiedliwości społecznej jest skierowanie spraw prywatnych osób ku dobru wspólnemu".

${ }^{43}$ Por. np. S. W y s z y ń s k i, Zapiski więzienne, s. 38.

44 Por. tamże, s. 14.

${ }^{45}$ Chodziło o Stoczek, por. tami̇e.

46 Tamże, s. 80. 
dliwości. Wątpliwości rozwiewa on sam: „Nie zmuszą mnie niczym do tego, bym ich nienawidził". ${ }^{47}$ Ponieważ miłość bliźniego, zwłaszcza wobec rodaków, jest elementarnym wymogiem i wyznacznikiem postawy patriotycznej, taka więc deklaracja poparta wieloma dowodarni konkretnych czynów aż nadto dobitnie świadczy o niemal heroicznym jej poziomie w życiu kardynała. Szczególnie mocno została natomiast wyeksponowana na wiadomość o śmierci B. Bieruta. Prymas był świadomy krzywd wyrządzonych Kościołowi przez aparat władzy, któremu zmarły przewodził. Skutkom jego antykościelnej działalności poświęcił w swych Zapiskach duży fragment, ${ }^{48} \mathrm{w}$ którym trudno wyczytać wzmiankę o jakimkolwiek dobru. Sam autor, wspominając o ekskomunice, którą zmarły zaciągnął z racji współdziałania $\mathrm{w}$ uwięzieniu kardynała Kościoła rzymskokatolickiego, przyznaje, że z trudnością, ale musi chcieć przede wszystkim Bożej sprawiedliwości. Jednak ma niezłomne postanowienie modlitwy w jego intencji, odprawienia mszy św., ,już teraz odpuszczając mojemu winowajcy". ${ }^{49}$

Niejako na marginesie należałoby zwrócić uwagę na duchową relację prymasa do całej ekipy funkcjonariuszy. Ten stosunek, budowany $\mathrm{i}$ przedstawiany $\mathrm{z}$ dużą delikatnością $\mathrm{i}$ świadczący o panowaniu prymasa nad wzajemnymi relacjami, ${ }^{50}$ jest bardzo jasny i klarowny - prymas wspomina o modlitwie wstawienniczej za dozorców stojących na korytarzach i za żołnierzy pilnujących terenu odosobnienia. Podłożem takiej wielkodusznej postawy jest niewątpliwe przeświadczenie o roli, jaką odgrywają oni nie tylko w konkretnym momencie jego życia, ale jako współpracownicy, mimo że nieświadomi, w dziele Bożej Opatrzności. Ta ofiara modlitwy i życzliwości z nadprzyrodzonych pobudek wobec prześladowców jest oczywistym znakiem miłości do konkretnych członków własnej ojczyzny, czyli ostatecznie jest znamieniem patriotyzmu. ${ }^{51}$ Zapiski wskazują bardzo wyraźnie, że

47 Tamże, s. 50.

48 Por. tamże, s. 222-224.

49 Tamże, s. 224. Notatka służbowa sporządzona na bazie donosu osoby współpracującej jeszcze wyraźniej wskazuje na chrześcijańską, i pośrednio patriotyczną, postawę prymasa: „Kardynał w chwili gdy się dowiedział o Jego śmierci, poszedł do kaplicy i b. długo się modlii, w następny dzień za Jego duszę odprawił żałobną Mszę św. zapowiedział nam również że z powodu śmierci Bieruta i żałoby państwowej, przez kilka dni wstrzyma się od spacerów”; por. W. J. W y s o c k i, Osaczanie Prymasa, s. 129-130. Zwraca uwagę praktyka ekspiacyjna, którą prymas podjął z racji uświadomienia sobie, że Bierut zmarł w ekskomunice.

50 Por. np. S. W y s z y ń s k i, Zapiski więzienne, s. 155.

51 Por. tamże, s. 123.Prymas pisze: „Wszyscy nasi przeciwnicy współdziałają z nami, przyczyniając się do dzieła wyzwolenia w nas Bożych sił (...). Cóż to znaczy, że chcą mi być «wrogami», kiedy ja widzę w nich przyjaciół i współpracowników w dziele mojego odkupienia?” 
taką postawę prymas świadomie ekstrapolował również na cały aparat władzy ówczesnej Polski, mimo że miał głębokie poczucie wyrządzonej mu przez rząd krzywdy, odnosząc tę opinię zwłaszcza do osoby ministra Franciszka Mazura. ${ }^{52}$ Stawiając rządzącym konkretne zarzuty, wynikające $\mathrm{z}$ ich niewłaściwej postawy przyjmowanej najpierw wobec prymasa, a potem prymasa-więźnia, ten ostatni „nie czuje uczuć nieprzyjaznych do nikogo z tych ludzi". ${ }^{33}$ Jest absolutnie przekonany o własnej postawie życzliwości wobec tych, którzy chcą go uważać za swego nieprzyjaciela, a którym on sam ,nie umiałby zrobić najmniejszej nawet przykrości". ${ }^{54}$

Prymas, doskonale zdając sobie sprawę, na czym polega prawdziwy patriotyzm, potrafił pokazać jego realizację, sprowadzając czasami ad absurdum zachowania i postawy otaczających go funkcjonariuszy. Z kpiącej oceny ich zachowań ${ }^{55}$ niewątpliwie wyłaniają się wskazówki cenne w kształtowaniu właściwej postawy patriotycznej w takich aspektach, jak: entuzjazm i wielkoduszność w spełnianiu obowiązków, „wkładanie serca” w wykonywaną planową i planowaną pracę, pracowitość i zaangażowanie, dbałość o narzędzia i warsztat pracy, dyskrecja i życzliwość i jeszcze wiele innych. Poczynione uwagi są więc ze wszech miar warte zastosowania, ponieważ prymas był osobą szczególnie kompetentną $\mathrm{w}$ nauczaniu postaw patriotycznych słowem i czynem. ${ }^{56}$

52 Franciszek Mazur był w latach 1950-1956 członkiem Biura Politycznego KC PZPR, odpowiadając za sprawy związane $\mathrm{z}$ Kościołem katolickim. Był jednym $\mathrm{z}$ trzech przedstawicieli Rządu, przewodnicząc Komisji Mieszanej, która przygotowywała tekst Porozumienia, por. biogram w: S. W y s z y ń s k i, Pro memoria. Zapiski z lat 1948-1949 i 1952-1953, Warszawa 2007, s. 668.

53 S. W y s z y ń s k i, Zapiski więzienne, s. 51.

54 Tamże.

55 Por. np. tamże, s. 95-103.

56 Uważna lektura jego tekstów choćby $\mathrm{z}$ czasów tylko jego posługi biskupiej świadczy o tym bardzo dobitnie, gdyż w wielu jego wystąpieniach elementy nawołujące do patriotyzmu i nauczające o nim są łatwo zauważalne. W przemówieniu do młodzieży na rozpoczęcie roku akademickiego 1 X 1951 r pisał: „Wczuwajcie się żywo w tętno dziejowe, które ożywczą krwią czynów bije w żyłach narodu naszego. Umiłujcie dzieje narodu w najdrobniejszych szczególach, we wszystkich zmaganiach o godny byt szczepu ojczystego. Umiłujcie każdy fragment historii: nie tylko wspaniałe - jak tysiąclecie, Bogurodzica, Skargowe wzywania do miłości ojczyzny i potężna wola Konstytucji majowej; nie tylko zwycięskie - jak Płowce, Grunwald, czy Wiedeń, ale $\mathrm{i}$ te bolesne - jak Legnica, Warna, czy Cecora. Bo w całości dziejów narodu tkwi jego duch i całość tych dziejów jest nauczycielką życia narodu. A dzieje narodu tak starajcie się zrozumieć, jak się kształtowały - w całej głębokiej treści złożonego życia narodu. Dzieje te tworzył naród katolicki, miłujący Boga i ludzi po chrześcijańsku. Zrozumieć więc można tylko dzieje wtedy, gdy stanie nam przed oczyma cała bogata celowość działania wierzącego narodu. 
Kolejnym elementem konstytuującym postawę patriotyczną jest wdzięczność wobec rodziców, którzy z jednej strony powołują do istnienia w konkretnej ojczyźnie, z drugiej, ucząc jej umiłowania, wskazują na jej absolutną nadrzędność. ${ }^{57} \mathrm{~W}$ życiu prymasa Wyszyńskiego tę postawę widać bardzo wyraźnie w listach do ojca, wysyłanych do niego $\mathrm{z}$ więzienia. ${ }^{58} \mathrm{O}$ swojej matce prymas mówi jako o tej, która ukierunkowała w nim powołanie maryjne. Gdy umierała, Stefan miał dziewięć lat. Oprócz miłości do Maryi uczyła go patriotyzmu, porządku i godności. ${ }^{59}$ Natomiast listy prymasa do ojca stanowią wzruszający i przekonujący dowód jego postawy patriotycznej z racji pietyzmu, z jakim zwraca się do niego. Zaczynają się one zwykle zwrotem „Najdroższy i Najlepszy mój Ojcze” i pełne są tkliwego uczucia oraz ogromnego zainteresowania jego codziennymi życiowymi sprawami. Prymas stara się w nich uspokajać ojca i przekazywać mu wyrazy otuchy, znając zaś jego zamiłowania, np. do lektury, dyskretnie prosi o czuwanie nad wzrokiem. Delikatna i wielkoduszna miłość synowska kazała prymasowi nieco odwlec napisanie jednego z listów, by ojciec otrzymał go jak najbliżej świąt Bożego Narodzęnia. Jak bowiem pisze: „Nie chciałbym, Drogi Ojcze, by te święta Twoje upłynęły $\mathrm{Ci}$ bez widomego znaku mego synowskiego oddania i czci". ${ }^{60} \mathrm{Z}$ tego wypływa również potrzeba przeproszenia ojca za to, że „nie podziękowałem za ostatni list” oraz, że „Twoje stara-

Wczuwajcie się w melodię duszy ojczystej, wyśpiewaną szeptem pieszczot matczynych, szczebiotem dziecięctwa waszego i mową wieszczów narodu. Niech przemówi do was całą głęboką treścią prawda słowa polskiego i niech was uczy szacunku dla słowa"; por. S. W y s z y ńs ki, Dzieła zebrane, t. I, s. 173-174. W podobny sposób o obowiązkach wobec ojczyzny w atmosferze zdrowego, wolnego od szowinizmu braterskiego patriotyzmu, który ma nauczyć nie tylko, gdy trzeba, umierać za ojczyznę, ale „żyć dla ojczyzny, dla niej pracować i wszystkimi talentami i zdolnościami swoimi zdobywać lepszą dla niej przyszłość” pisał w Liście do redakcji „Tygodnika Powszechnego" z listopada 1952 r.; por. tamże, s. 207-208.

${ }^{57}$ Kardynał tak o tym pisał w liście do ojca z dn. 8 IX 1955: „Przekazałeś mi życie i lękasz się o to, aby to życie było godne. Czyż trzeba Cię zapewniać o tym, że jest to najważniejsza troskamoja? Wszak jedno mam tylko życie i nie mogę go niczym przyćmić. O to się módl”; tenże, Zapiski więzienne, s. 180.

58 Zapiski więzienne zawierają 15 listów Wyszyńskiego do ojca, por. s. 41, 44, 49, 69, 82, 111, 118, 132, 139, 148, 158, 169, 180, 185, 202.

59 Por. tamże, s. 32, por. E. K. C z a c z k ow s k a, Kardynat Stefan Wyszyński, Warszawa 2011, s. 35-38. Jednak zachowywał o niej gorącą synowską pamięć, np. gorąco dziękując za przysłanie jej fotografii wraz ze zdjęciem Obrazu Matki Boskiej Częstochowskiej, por. list do ojca z dn. 14 XII 1954 w: por. S. W y s z yń s k i, Zapiski więzienne, s. 118-119; pamięta również o rocznicy jej śmierci, odprawiając w jej intencji msze św., por. tamże, s. 185.

${ }^{60}$ Tamże, s. 49. 
nia o możność widzenia się ze mną naraziły Cię na tyle cierpienia. ${ }^{61}$ Słowa te dyktuje prymasowi delikatność synowskich uczuć, mimo że zdaje sobie sprawę z bardzo ograniczonego własnego wpływu na istniejące okoliczności. Zwraca również uwagę subtelne wezwanie, by myśli nie były ,pozbawione chrześcijańskich uczuć wobec wszystkich ludzi, bez wyjątku". ${ }^{62}$ Niewątpliwie uwięziony prymas zdawał sobie sprawę, jak łatwo - mimo formacji duchowej - ulec pokusie nienawiści, zwłaszcza w świetle konkretnych, boleśnie dotykających wydarzeń. Wezwanie do miłości rodaków i przyjęcia wobec nich postawy życzliwości jest więc niewątpliwym znakiem kultywowanej przez niego postawy patriotycznej. Nie trzeba dodawać, że przez cały czas internowania prymas otaczał swojego ojca i całą rodzinę gorąca wstawienniczą modlitwą.

Zagadnieniem szczególnym $\mathrm{w}$ analizie patriotycznej postawy Prymasa Tysiąclecia, ukazywanej podczas jego uwięzienia, są jej teologiczne i duchowe fundamenty. Jest oczywiste, że z formalnego punktu widzenia wypływają one przede wszystkim, jak wskazano wyżej, $\mathrm{z}$ praktyki życia ewangelijnym przykazaniem miłości, jednak $\mathrm{w}$ postawie kard. Wyszyńskiego widać pewne charakterystyczne elementy teologiczne, które ją uformowały. Wkładem doczesnym w tę postawę, niejako elementem „materialnym” była bez wątpienia trudna sytuacja Kościoła w Polsce. Opierając się na wnioskach W. J. Wysockiego, ${ }^{63}$ można stwierdzić, że dążeniem ówczesnych władz było dokonanie rozłamu wśród duchowieństwa na „postępowych”, przyjmujących serwilistyczną postawę wobec władz i „wrogą” resztę. Zacieśnianie wrogiego działania wobec Kościoła spowodowało u prymasa Wyszyńskiego przekonanie, że $\mathrm{z}$ racji minimalnego zainteresowania Zachodniej Europy sprawy Kościoła w Polsce należy rozgrywać na miejscu, idąc na jakieś ustępstwa ze świadomością, że pewnej granicy nie można przekroczyć. ${ }^{64}$ Wycofując się z mniej ważnych pozycji, Kościół - zdaniem prymasa - powinien wzmocnić morale społeczeństwa. Z tego więc bierze się nieugięta patriotyczna postawa kardynała

61 Tamże, s. 111

62 Tamże, s. 70.

63 W. J. W y s o c k i, Osaczanie Prymasa, s. 18-21.

64 Por. tamże, s. 20. Granicą ustępstw był memoriał opracowany na Konferencji Episkopatu Polski w Krakowie 8 V 1953 r. znany jako Non possumus, por. S. W y s z y ń s k i, Dzieła zebrane, t. I, s. 247-260. 
podczas uwięzienia. ${ }^{65}$ Efektem takiej polityki było zawarcie, w permanentnie niesprzyjającej i wrogiej atmosferze tworzonej przez władze, 14 kwietnia 1950 r. Porozumienia między Episkopatem Polski i rządem PRL, ${ }^{66}$ nota bene regularnie niedotrzymywanego przez stronę rządową.

Niezwykle trudna walka ze złem i przeciwnościami spowodowała wzmocnienie nadprzyrodzonego spojrzenia prymasa na sprawy ojczyzny i patriotyzmu. W jednym z wcześniejszych listów do ojca Wyszyński pisze, że ,we wszystkim, co człowieka w życiu spotyka, trzeba dopatrzeć się śladów Bożej miłości" ${ }^{67}$ Do tej myśli prymas będzie wracał szczególnie często, zwłaszcza w początkach uwięzienia, gdy poszukiwal nadprzyrodzonego oparcia i pocieszenia w trudnej sytuacji pozbawienia wolności. ${ }^{68}$ Szczególny zaś rozwój takiego nadprzyrodzonego spojrzenia na miłość ojczyzny da się zauważyć w Zapiskach z okresu pobytu w Komańczy, a więc w ostatnim okresie uwięzienia. Śledząc rozwój duchowy w świetle jego dziennika, można by nawet pokusić się o zdefiniowanie pierwszych okresów uwięzienia jako pasma oschłości duchowych, następnie wyodrębnięnie momentu przełomu i następującego po nim okresu intensywnego i stałego rozwoju zażyłości z Bogiem. Przybliżenie tego zagadnienia przekracza jednak ramy niniejszego artykułu.

Teksty prymasa o ojczyźnie z okresu Komańczy mają charakter permanentnej modlitwy, niejako wylewającej się z jego pełnego wdzięczności serca. Taką modlitwę, pełną uległości i oddania woli Bożej, zamieścił prymas pod datą 9 marca $1956 \mathrm{r}$. W tej modlitwie, zbudowanej na zasadzie kontrastu, prosi Boga „o wszystko straszne” dla siebie, aby „wszystko straszne ominęło Twój Kościół w Polsce

${ }^{65}$ Uwięziony w Komańczy Wyszyński w związku z tym pisał: „Muszę z głęboką pokorą rozumieć, żeś Ty mnie wybrał do tej rozgrywki, w której idzie o Imię Twoje i o prawo Twoje do ziemi polskiej, o prawo Narodu do Ciebie, o prawo Kościoła świętego(...) Muszę widzieć ten najdelikatniejszy punkt walki wiary $\mathrm{i}$ niewiary w sobie $\mathrm{i}$ na sobie.(...) To jest tragiczna prawda, która wymaga bohaterskiej pokory. Sytuacja(...)zależy od tego, jak ja wytrzymam próbę. Oni wszyscy, nie wyłączając Rządu i Partii, patrzą w tej chwili na Komańczę"; por. te n że, Zapiski więzienne, s. 240.

${ }^{66}$ T e nż e, Dzieła zebrane, t. I, s. 243-244; por. W. J. W y s o c k i, Osaczanie Prymasa, s. $22-25$.

${ }^{67}$ S. W y s z y ń s k i, Zapiski więzienne, s. 44.

${ }^{68}$ Por. tamże, s. 31. W swej refleksji nad życiem Anieli Salawy prymas zauważa: „Im bardziej zdobywał ją sobie Bóg, tym więcej oddawała się ludziom w przedziwnej gotowości ofiary i usłużności, a nawet zastępczego cierpienia. Jest to doskonała patronka na czasy współczesne”; tamże. 
i wiemy naród katolicki”. ${ }^{69}$ Proszenie ,przeciwko sobie”, a więc o to, co dotychczas wzbudzało w nim lęk, ale mogło służyć Kościołowi, wskazuje na coraz głębsze nadprzyrodzone rozumienie nie tylko swojej sytuacji, wymagającej heroicznej postawy patriotycznej, ale przede wszystkim na duchowe oczyszczenie ${ }^{70}$ i to $\mathrm{w}$ różnych aspektach, np. ubóstwa $^{71}$. Pogłębiająca się relacja $z$ Bogiem powoduje, że w swoich modlitwach kardynał przechodzi coraz częściej na bezpośrednią osobistą relację z Bogiem, pozostawiając niejako „w tle”, zawsze ważny, chociaż nie zawsze już werbalizowany, problem wstawiennictwa za ojczyznę, która jednak cały czas jest w jego modlitwach obecna. Jest oczywiste, że wskazana już wyżej maryjna postawa prymasa $\mathrm{w}$ tym okresie również rozwija się intensywnie w aktach miłości, wierności, oddania i dziękczynienia za opiekę nad Polską, zwłaszcza w kontekście Jasnogórskich Ślubów Narodu. ${ }^{72}$

Należy jeszcze zwrócić uwagę, że prymas nieustannie wskazuje praktyczne sposoby realizowania postawy patriotycznej. W ostatniej wygłoszonej przed uwięzieniem homilii, we wspomnienie bł. Ładysława $z$ Gielniowa ${ }^{73}$ kard. Wyszyński pokazuje kilka cech miłości, również umiłowania ojczyzny, takich jak: odwaga, męstwo w przeciwnościach, działanie pokorne a nie „na pokaz”, w końcu zaś religijność, ale nie krzykliwa, tylko cicha. To wszystko jednak jest możliwe dopiero przy postaw, opartej na sumieniu, przyjęcia Bożej prawdy. Obecny w homilii przewodni motyw wolności jak echo wraca ponad rok później: „Obrona Jasnej Góry dziś - to obrona chrześcijańskiego ducha narodu, to obrona kultury rodzimej, obrona jedności serc ludzkich - w Bożym Sercu, to obrona swobodnego oddechu człowieka, który chce wierzyć bardziej Bogu niż ludziom, a ludziom - po Bożemu". ${ }^{74}$

Postawa patriotyczna wymaga miłości i szacunku wobec ojczyzny i rodaków, a więc również wobec tych, którzy z mandatu społeczne-

69 Tamże, s. 220

70 Początki tych procesów można dostrzec już w Prudniku, por. tamże, s. 127.

71 Por. tamze, s. 245.

72 Por. tamże, s. 243, 244, 247, 249. 250. Ten teocentryczno-maryjny aspekt oddania się woli Bożej podkreśla dla prymasa wartość trzech lat uwięzienia, które były nieocenione dla chwały Bożej, Kościoła i dobra jego duszy. Podkreślając to, Wyszyński zamyka wszystko „w godzinie mego aresztowania swoim Te Deum i Magnificat”, zapiska z dn. 25 IX 1956 r..; por. tamże, s. 250-251.

73 T e n ż e, Dzieła zebrane, t. I, s. 238-242; por. komentarz prymasa w związku z nią w: t e n ż e, Zapiski więzienne, s. 11.

74 Tami̇e, s. 120. 
go sprawują w niej władzę. Sytuacja staje się jednak znacznie mniej klarowna, gdy osoby predestynowane do szacunku $\mathrm{z}$ racji pielęgnowania urzędu nie zasługują nań na skutek rażących niedociągnięć moralnych w swoim postępowaniu. Prymas wiele razy stawał wobec konieczności oceny takich ludzi, konstatując, czemu niejednokrotnie dawał wyraz w Zapiskach, nie tylko niepoprawne $\mathrm{z}$ etycznego i społecznego punktu widzenia zachowanie władz PRL wobec niego, ${ }^{75}$ ale również doświadczając takiego postępowania podczas swojego uwięzienia. $^{76}$ Niewątpliwie jednak w tej trudnej sytuacji zawsze potrafił odnaleźć się jako patriota, miłujący ojczyznę i pragnący jej pomyślności. Zdecydowanie protestując i jednoznacznie potępiając niewłaściwe etycznie akty, przestrzegał przed nienawiścią do człowieka dopuszczającego się zła. Ten drugi element został już przedstawiony wcześniej, teraz należałoby skoncentrować się, przynajmniej ogólnie, na elementach patriotycznej postawy prymasa $\mathrm{w}$ jego relacjach $\mathrm{z}$ rządem PRL.

Poza wszelką wątpliwością jest fakt, że prymas Wyszyński doznał wielu przykrości i naruszenia osobistej godności ze strony rządu PRL. Te doświadczenia miały prawo zaważyć na jego relacjach wobec przedstawicieli strony rządowej, choćby przez ograniczanie kontaktów z obawy przed kolejnymi moralnymi i psychicznymi szykanami. W postawie uwięzionego prymasa widać staranie, by indywidualnych złych doświadczeń nie przenosić na relacje z władzami lub nie tworzyć $z$ tego emocjonalnego podłoża do dalszych, ciągle przecież trudnych, ale - z punktu widzenia interesów kraju - potrzebnych kontaktów. W postawie prymasa uderza więc wielki wysiłek, aby każdy nowy kontakt budować jakby w oderwaniu lub w zapomnieniu o negatywnych doświadczeniach. W tych relacjach wyczuwa się, z jednej strony, jego wielką kulturę i delikatność w obchodzeniu się z ludźmi, z drugiej natomiast - zdrowy rozsądek i „chłodne” respektowanie przepisów. Pozwala mu to spokojnie negować lub wnikliwie pytać o podstawy działań, wiedząc o właściwym sposobie ich realizacji. Na tej podstawie, znając swoje racje, nie cofa się przed postawą uprzejmej stanowczości. Jego patriotyczna postawa przejawia się również w tym, że do końca zachowuje się zgodnie z prawem, co

\footnotetext{
${ }^{75}$ Por. W. J. W y s o c k i, Osaczanie Prymasa, s. 27-40; E. K. C z a c z k o w s k a, Kardynat Stefan Wyszyński, s. 85-171 ; J. Ż a r y n, Bilans pierwszego pięciolecia. Internowany Prymas o relacjach Państwo - Kościót w latach 1948-1953, AK 142(2004) 1, s. 24-32.

${ }^{76}$ Por. E. K. C z a c z k o w s k a , Kardynat Stefan Wyszyński, s. 177-237.
} 
uznaje za formę szacunku wobec państwa. Jego odpowiedzi i protesty noszą więc znamię nie tylko znajomości wymogów formalnych, ale przede wszystkim klarowności postaw i wewnętrznej uczciwości wobec kraju i rządu, nota bene pisanego w Zapiskach zawsze wielką literą. ${ }^{77} \mathrm{Z}$ takiej właśnie świadomości obowiązujących zasad oraz poprawności własnej postawy wypływa zdecydowana, czasami nawet miażdżąca, krytyka działania władz wobec niego jako więźnia, oparta na wskazywaniu proceduralnych niezgodności z Konstytucjąa ${ }^{78}$ bra$\mathrm{ku}$ uzasadnień prawnych dla postępowania władz, ${ }^{79}$ łamaniu dobrych obyczajów międzyludzkich ${ }^{80}$ lub zwykłym cynizmie. ${ }^{81} \mathrm{~W}$ świetle takich postaw strony rządowej wobec prymasa zwraca uwagę powaga, $\mathrm{z}$ jaką on sam nieodmiennie traktuje rząd PRL. Już w Stoczku prymas prosi, widząc w tym swój obowiązek, o wyjaśnienie własnej sytuacji, gdyż „milczenie mogłoby uchodzić za wyrzeczenie się moich praw lub za lekceważenie zarzutów mi stawianych, zwłaszcza przez tak wpływowych przedstawicieli PZPR jak generał Edward Ochab". ${ }^{82}$ Jednak, zdając sobie sprawę $\mathrm{z}$ rangi okoliczności, roztropnie wskażuje potencjalnych adresatów swoich listów, dbając o to, by w środowisku adresata pismo „było potraktowane wnikliwie i poważnie”. ${ }^{83}$ Przebijająca $z$ postawy i sposobu załatwiania spraw powaga prymasa oraz szacunek, jaki miał wobec państwa i jego władz, wskazuje na jego heroiczną i wielkoduszną miłość ojczyzny godną podkreślenia, zwłaszcza w kontekście doznawanych przykrości.

Postawa mężnego patriotyzmu znalazła swoje apogeum w wydarżeniu zanotowanym w Zapiskach pod datą 7 sierpnia 1955 r. ${ }^{84}$ Był to przyjazd ppłk. Józefa Dziemidoka, dyrektora Departamentu VI Kornitetu do Spraw Bezpieczeństwa Publicznego i złożenie propozycji ,zamieszkania w jakimś klasztorze, według wspólnego wyboru". ${ }^{55} \mathrm{~W}$ zamian za to prymas miał się, m.in., wyrzec wypełniania jakichkolwiek

77 Por. np. S. W y s z y ń s k i, Zapiski więzienne, s. 12-14.

78 Por. tamże, s. 200 (rewizja podczas nieobecności właściciela).

79 Por. tamże.

80 Por. tamże, s. 55 (jedynie odczytywanie i późniejsze zatrzymywanie listów kard. Wyszyńskiego pisanych do ojca).

81 Por. tamże, s. 61.

82 Tamże, s. 45. Gen. E. Ochab w okresie uwięzienia prymasa był członkiem Biura Politycznego KC PZPR, por. S. W y s z y ń s k i, Pro memoria, s. 676.

83 T e n ż e, Zapiski więzienne, s. 46.

84 Por. tamże, s. 174-177; por. E. K. C z a c z k o w s k a, Kardynat Stefan Wyszyński, s. 198.

85 S. W y s z y ń s k i, Zapiski więzienne, s. 174. 
funkcji publicznych. Po kilkugodzinnym namyśle i modlitwie prymas Wyszyński przedstawił swoje indywidualne Non possumus, nie godząc się na dobrowolne przyjmowanie warunków uwięzienia, uważając słusznie, że mogłoby być to poczytane za akceptację uchwały rządu o aresztowaniu go i tym samym za przyznanie się do winy. Dodatkowym argumentem do odmowy była niepewność kardynała, czy wyrażenie zgody nie będzie powodem gorszących komentarzy w społeczeństwie. Sam zaś uzasadnia swoją decyzję w piękny sposób, świadczący o jego głębokim umiłowaniu ojczyzny i poszanowaniu jej praw: „Nie mogę przecież współdziałać w naradach nad nowym pozbawieniem mnie wolności, nad tym, jak mam zostać dobrowolnym niewolnikiem. Wyrzeczenie się dobrowolne wolności jest wyrazem upadku moralnego obywatela. Gdybym dziś nie chciał bronić swych praw do wolności, nie umiałbym - gdyby zaszła potrzeba - bronić i wolności Ojczyzny. Tylko taki obywatel umie bronić wolności, który doznaje wolności w swej Ojczyźnie. Obywatel uciskany w swej Ojczyźnie, nie jest zdolny jej bronić”. ${ }^{86}$

Ważnym elementem, który stanowił nieustannie przedmiot refleksji prymasa i gdzie odbija się wyraźnie jego patriotyczne nastawienie, jest naród. Bez wątpienia przeważająca część jego refleksji na ten temat pochodzi z tego okresu życia kardynała, gdy ma on bezpośredni kontakt ze swymi rodakami, a więc spoza czasów przedstawionych w Zapiskach. Jednak nawet te niewielkie przecież kontakty ze „światem zewnętrznym" generowały w myślach kardynała różne refleksje, którym, choćby krótko, warto poświęcić uwagę. Uderza, przede wszystkim, dobra opinia prymasa o narodzie. ,Jednak Polacy to Naród wysokiej kultury", ${ }^{87}$ zanotował prymas w kontekście zafałszowanych i krzywdzących jego i episkopat opinii rozsiewanych przez władze PRL, a którym to treściom ludzie, zwłaszcza prości, mimo braku bieżącej informacji, nie chcieli dać wiary. Opinia ta staje się jeszcze bardziej miarodajna, gdy się zważy, że wypływa ze stwierdzonego przez prymasa faktu niedoceniania przez władze PRL ,wyczucia możliwości i zdolności odbiorczych narodu" ${ }^{88}$ Niewątpliwie prymas jest przekonany, że pewna część narodu nie dała się uwieść propagandowemu zamętowi rozpętywanemu wokół jego losów. Daje temu wyraz, mając świadomość rangi Kościoła katolickiego wśród Pola-

\footnotetext{
${ }^{86}$ Tamże, s.

${ }^{87}$ Tamże, s. 30

${ }^{88}$ Tamie.
} 
ków, jak również swojego w nim miejsca i znaczenia. Z oczywistych powodów ta argumentacja nie trafia do przedstawiciela władzy, co bezpośrednio powoduje wyrażenie przez prymasa zatroskania o Polskę i naród, które to podmioty w wyniku konkretnych posunięć strony rządowej mogą zostać narażone ,na wiele ataków ze strony całego cywilizowanego świata", czego on chciałby zdecydowanie uniknać dla tegoż narodu dobra. ${ }^{89}$ Doświadczenia pobytu w więzieniu niewątpliwie umocniło w prymasie wszystkie te uczucia, które żywił wobec swojego narodu. Dlatego zauważalna nuta spokoju, gdy komentuje teksty, które wychodząc z kręgów tak episkopatu, jak i rządu, uderzały boleśnie i niesprawiedliwie we wszystko to, nad czym on sam do momentu uwięzienia pracował, przede wszystkim zaś nad unormowaniem, z braku konkordatu, na drodze Porozumienia, relacji między państwem a Kościołem, aby ten ostatni mógł spokojnie rozwijać się, pełniąc swoją misję. ${ }^{90}$ Jak dużo światła na patriotyzm prymasa rzuca choćby tylko taki epizod. Zamieszczona w Deklaracji Episkopatu prośba skierowana do rządu, aby „ks. abp Wyszyński mógł zamieszkać w jednym z klasztorów", spowodowała u prymasa zarówno odruch chęci zrozumienia postawy biskupów, jak i współczucie wobec narodu, który takim postawieniem sprawy musiał zostać mocno dotknięty w swym poczuciu wierności wobec Kościoła. ${ }^{91}$

Streszczenie patriotycznej postawy kard. Stefana Wyszyńskiego, Prymasa Tysiąclecia, można odnaleźć już na pierwszych stronach $Z a$ pisków. Uwięziony w Rywałdzie snuje rozważania nad dotychczasową sytuacją polityczną, społeczną i religijną w świetle relacji Kościół - rząd. ${ }^{92}$ Daje tam bardzo wnikliwą i celną jej analizę, uzasadniając wszystkie podjęte przez siebie kroki i osadzając je w realiach tamtych okoliczności. Patrząc więc z perspektywy całego okresu internowania, nie sposób oprzeć się przekonaniu, że prymas przez te trzy

89 Por. tamíe, s. 26.

90 Por. tamże, s. 206-207. Chodzi tu o cztery dokumenty, przedstawione opinii publicznej w zestawieniu obok siebie, co prymas nazywa perfidią. Te dokumenty to: Komunikat Prezydium Rządu PRL; Deklaracja episkopatu Polski; Wybór przewodniczacego Episkopatu; Oświadczęnie Wiceprezesa Rady Ministrów Józefa Cyrankiewicza; por. S. W y s z y ń s k i, Dzieła zebrane, t. II, s. 234-235.

91 Por. t e n ż e , Zapiski więzienne, s. 206-207.

92 Por. tamże, s. 18-25. 


\section{LESZEK WIANOWSKI}

lata po prostu spokojnie i konsekwentnie żył - na miarę danych mu możliwości, rozwijając i pielęgnując własną formację - sprawami Kościoła i ojczyzny, mając zawsze za naczelną przesłankę dobro tych obydwu rzeczywistości, wielkodusznie i z głębokim wewnętrznym przekonaniem obdarowując je swoją miłością, przywiązaniem i czcią.

Leszek WIANOWSKI 